\title{
OCORRÊNCIA DE GENES CODIFICADORES DE ENTEROTOXINAS ESTAFILOCÓCICAS EM AMOSTRAS DE LEITE DE VACAS
}

\section{OCCURRENCE OF GENES ENCODING STAPHYLOCOCCAL ENTEROTOXINS ISOLATED FROM COW'S MILK SAMPLES}

\author{
Érica Chaves Lúcio ${ }^{1 *}$ \\ Milena Silva Albuquerque ${ }^{1}$ \\ Júnior Mário Baltazar Oliveira ${ }^{1}$ \\ Gisele Veneroni Gouveia ${ }^{1}$ \\ Mateus Matiuzzi Costa ${ }^{1}$ \\ Rinaldo Aparecido Mota ${ }^{1}$ \\ José Wilton Pinheiro Junior ${ }^{1}$ \\ 1Universidade Federal Rural de Pernambuco, Recife, PE, Brasil. \\ *Autora para correspondência - erica.c.l@hotmail.com
}

\section{Resumo}

Objetivou-se com este trabalho identificar a ocorrência de genes codificadores de enterotoxinas estafilocócicas (sea, seb, sec e seg) e do gene da toxina 1 responsável pela síndrome do choque tóxico (tst) em isolados de Staphylococcus aureus procedentes de casos de mastite bovina, no estado de Pernambuco, Brasil. Foram analisados 93 isolados e observou-se a presença de genes toxigênicos em $20(21,6 \%)$ deles, dos quais $11(55,0 \%)$ foram positivos para o gene tst, sete $(35,0 \%)$ para o gene sec e dois $(10,0 \%)$ para o gene $s e g$. Dentre os 20 isolados que amplificaram na PCR para presença dos genes sec, seg e tst, $16(80,0 \%)$ foram positivos apenas para um gene e quatro $(20,0 \%)$ foram positivos para dois genes ( $\mathrm{sec}$ e $t s t)$. Das 17 propriedades de onde as amostras tiveram origem, sete $(41,2 \%)$ apresentaram amostras positivas para pelo menos um dos genes sec, seg e tst. Este é primeiro registro de ocorrência dos genes codificadores das enterotoxinas SEC e TST-1 em amostras de leite de vacas com mastite no estado de Pernambuco, Brasil.

Palavras-chave: mastite; patogênese; PCR; Staphylococcus aureus.

\begin{abstract}
The objective of this study was to identify the occurrence of genes expressing staphylococcal enterotoxin ( $\mathrm{sea}, \mathrm{seb}, \mathrm{sec}$, and $\mathrm{seg}$ ) and the toxin gene 1 of toxic shock syndrome (tst) in Staphylococcus aureus coming from cases of bovine mastitis in the state of Pernambuco, Brazil. We analyzed 93 isolates and we observed the presence of toxigenic gene in $20(21.6 \%)$ samples, of which $11(55.0 \%)$ were positive for $t s t$ gene, seven $(35.0 \%)$ for the sec gene, and two (10.0\%) for the seg gene. Of the 20 isolates amplified in PCR for the presence of the sec gene, seg and tst, $16(80.0 \%)$ were positive for only one gene and four $(20.0 \%)$ were positive for two genes
\end{abstract}


( $\mathrm{sec}$ and $t s t)$. Of the 17 properties from which the samples originated, seven $(41.2 \%)$ had positive samples for at least one of the genes sec, seg, and tst. This is the first record of the occurrence of the genes encoding the enterotoxin SEC and TST-1 in milk samples from cows with mastitis in the state of Pernambuco, Brazil.

Keywords: mastitis; pathogenesis; PCR; Staphylococcus aureus.

Recebido em: 02 de setembro de 2016

Aceito em: 08 de março de 2018

\section{Introdução}

Devido às suas propriedades de multiplicação e metabolismo, Staphylococcus aureus é a principal espécie gram-positiva causadora de mastite bovina. Possui capacidade de produzir toxinas, incluindo as enterotoxinas estafilocócicas (EEs) e a toxina 1 da síndrome do choque tóxico (TSST-1), que são classificadas como superantígenos ${ }^{(1)}$.

Pesquisas em todo mundo são realizadas para identificar a presença dessas enterotoxinas em casos de mastite. Na Turquia foi verificada a ocorrência de 23,6\% (25/106) de isolados de $S$. aureus procedentes de casos de mastite bovina subclínica positivos para o gene sea e 1,9\% $(2 / 106)$ para o gene $s e b^{(2)}$. No Irã detectou-se 31,9\% (29/91) de isolados positivos para os genes das enterotoxinas clássicas (sea-see) ${ }^{(3)}$. Já na Alemanha foram avaliados 94 isolados de $S$. aureus, em que 36,2\% (34/94) foram positivos para o gene tst, 3,2\% (3/94) para o gene sea, $2,1 \%(2 / 94)$ para o gene $s e b, 23,4 \%(22 / 94)$ para o gene $\sec$ e $4,3 \%(4 / 94)$ para o gene $s e d^{(4)}$.

No Brasil, o primeiro estudo a detectar a ocorrência da toxina TSST-1 foi realizado por Cardoso et al. ${ }^{(5)}$, que avaliaram 127 amostras de $S$. aureus isoladas de casos de mastite de bovinos leiteiros em Minas Gerais, o que representou 47,2\% dos isolados. Outros estudos foram conduzidos para determinar a ocorrência das principais enterotoxinas em isolados de Staphylococcus spp. obtidos a partir de leite bovino. Lamaita et al. ${ }^{(6)}$ detectaram a ocorrência do gene sea e seb em 3,5\% (5/138) e 9,3\% (13/138) das amostras, respectivamente. Enquanto Dias et al. ${ }^{(7)}$ detectaram a ocorrência de $60,0 \%(87 / 145)$ para o gene sea; $37,9 \%(55 / 145)$ para o gene seb e 6,9\% (10/145) para o gene sec. No estado de Pernambuco, foram detectados os genes seg, seh, sei e sej em 80,2\% (65/81) das amostras analisadas ${ }^{(8)}$.

A identificação dos genes codificadores de enterotoxinas em isolados de Staphylococcus aureus procedentes de vacas com mastite é de fundamental importância uma vez que o conhecimento dos fatores de virulência de $S$. aureus fornece dados relevantes para os produtores de leite e derivados, indicando a necessidade de adoção de estratégias efetivas de controle e prevenção da mastite, além de prevenir casos de toxinfecções alimentares. Dessa forma, objetivou-se com este estudo verificar a ocorrência de genes que codificam enterotoxinas estafilocócicas em isolados de Staphylococcus aureus procedentes de casos de mastite bovina, no estado de Pernambuco, Brasil. 


\section{Material e Métodos}

Foram utilizados no presente estudo 93 isolados de $S$. aureus do banco de culturas do Laboratório de Doenças Infecciosas, da Unidade Acadêmica de Garanhuns, Universidade Federal Rural de Pernambuco. Os isolados foram obtidos a partir de amostras de leite de vacas com mastite, em 17 propriedades do estado de Pernambuco.

Os isolados bacterianos do banco de culturas foram mantidos em microtubos de polipropileno, contendo 1,0 mL de caldo infusão de cérebro e coração (BHI) (DIFCO ${ }^{\circledR}$, U.S.A, Inc.), com $10 \%$ de glicerol. As culturas-estoque estavam armazenadas a $20{ }^{\circ} \mathrm{C}$ e identificadas de acordo com a numeração dos animais. A recuperação das cepas selecionadas para todas as análises foi realizada pela incubação dos microtubos por 24 horas, a $37{ }^{\circ} \mathrm{C}$ em estufa. Após essa recuperação, as bactérias foram isoladas em ágar base acrescido de $5 \%$ de sangue desfibrinado de ovino, pela técnica de semeadura em estrias por esgotamento, de modo a garantir a obtenção de colônias puras. As placas foram incubadas em estufa microbiológica, a $37{ }^{\circ} \mathrm{C}$ por 24 a 48 horas.

Para extração do DNA, dez unidades formadoras de colônias (UFC) de cultivo foram colocadas em $300 \mu 1$ de TE (10 mM Tris/HCL pH 8; 1 mM EDTA), sendo homogeneizadas em vórtex. Acrescentou-se $70 \mu \mathrm{l}$ de SDS $10 \%$ e novamente homogeneizou-se. Em seguida, foram adicionados $100 \mu \mathrm{l}$ de $\mathrm{NaCl}_{2} 5 \mathrm{M}$ e $80 \mu \mathrm{CTAB} / \mathrm{NaCl}$ e incubou-se a $65{ }^{\circ} \mathrm{C}$ por 20 minutos. Posteriormente foram acrescidos $700 \mu 1$ de clorofórmio/álcool isoamílico (24:1) e homogeneizou-se por inversão. As amostras foram centrifugadas a $11.750 \mathrm{~g}$ durante 5 minutos. Foi transferida a primeira fase para outro tubo e acrescentados $450 \mu 1$ de isopropanol $100 \%$. Os tubos foram invertidos e deixados em gelo por 20 minutos. Após esse período, as amostras foram centrifugadas a $11.750 \mathrm{~g}$ durante 15 minutos, desprezando-se o sobrenadante e acrescentados $500 \mu 1$ de etanol $70 \%$. Em seguida, foram centrifugadas a $11.750 \mathrm{~g}$ por 10 minutos e novamente desprezado o sobrenadante. As amostras foram eluidas em $80 \mu 1$ de TE e incubadas a $45{ }^{\circ} \mathrm{C}$ por 60 minutos. Ao término, foram armazenadas a $-20{ }^{\circ} \mathrm{C}^{(9,10)}$. Para a identificação dos genes codificadores de enterotoxinas estafilocócicas (genes sea, seb, sec, seg) e da toxina 1 da Síndrome do Choque Tóxico ( $t s t$ ) foi realizada PCR, com um volume final de $25 \mu$, em que $17 \mu 1$ foram de mix contendo $2 \mathrm{mM}$ de $\mathrm{MgCl}_{2} ; 0,4 \mathrm{pmol}$ dos primers (Tabela 1);0,4mM dos desoxirribonucleotídeos; tampão de enzima $1 \mathrm{X}$ e $1.5 \mathrm{U}$ de Taq DNA polimerase e $8 \mu 1$ do DNA de cada amostra. As reações de amplificação de cada gene são observadas na Tabela 2.

Os produtos das PCRs foram submetidos à eletroforese em gel de agarose a 1,5\% corado com brometo de etídio (1,0 $\mathrm{mgmL}^{-1}$ ) (PROMEGA, U.S.A), visualizados sob luz ultravioleta e documentados em sistema de captura de imagem. O DNA de $S$. aureus 89 cTP ${ }_{2}$ FUNED e $S$. aureus FRI 361 foram usados como controles positivos. 
Tabela 1. Iniciadores utilizados para a amplificação dos genes estudados

\begin{tabular}{|c|c|c|c|}
\hline Gene & Primer & Sequência $\left(5^{\prime}-3\right)$ & $\begin{array}{r}\text { Fragmento } \\
\text { amplificado }\end{array}$ \\
\hline \multirow[b]{2}{*}{$n u c^{(11)}$} & $n u c F$ & GCGATTGATGGTGATACGGTT & \multirow[b]{2}{*}{$279 \mathrm{pb}$} \\
\hline & nuc $R$ & $\begin{array}{l}\text { AGCCAAGCCTTGACGAACTAAA } \\
\text { GC }\end{array}$ & \\
\hline \multirow{2}{*}{$\operatorname{sea}^{(12)}$} & SEA3 & CCTTTGGAAACGGTTAAAACG & \multirow{2}{*}{$127 \mathrm{pb}$} \\
\hline & SEA4 & TCTGAACCTTCCCATCAAAAAC & \\
\hline \multirow{2}{*}{$s e b^{(13)}$} & SEB-1 & GTATGGTGGTGTAACTGAGC & \multirow{2}{*}{$164 \mathrm{pb}$} \\
\hline & SEB-2 & CCAAATAGTGACGAGTTAGG & \\
\hline \multirow{2}{*}{$\sec ^{(12)}$} & SEC3 & CTCAAGAACTAGACATAAAAGCTAGG & \multirow{2}{*}{$271 \mathrm{pb}$} \\
\hline & SEC4 & TCAAAATCGGATTAACATTATCC & \\
\hline \multirow{2}{*}{$\operatorname{seg}^{(14,15)}$} & SEG-1 & CGTCTCCACCTGTTGAAGG & \multirow{2}{*}{$328 \mathrm{pb}$} \\
\hline & SEG-2 & CCAAGTGATTGTCTATTGTCG & \\
\hline \multirow{2}{*}{$t s t^{(12)}$} & TST3 & AAGCCCTTTGTTGCTTGCG & \multirow{2}{*}{$445 \mathrm{pb}$} \\
\hline & TST6 & ATCGAACTTTGGCCCATACTT T & \\
\hline
\end{tabular}

Tabela 2. Reações de amplificação dos genes

\begin{tabular}{|c|c|c|c|c|c|c|}
\hline & nuc & sea & $s e b$ & $\mathrm{sec}$ & seg & tst \\
\hline Ciclo inicial & $\begin{array}{l}94^{\circ} \mathrm{C} / \\
5 \mathrm{~min} .\end{array}$ & $\begin{array}{l}95^{\circ} \mathrm{C} / \\
5 \mathrm{~min} .\end{array}$ & $94^{\circ} \mathrm{C} / 5 \mathrm{~min}$. & $\begin{array}{l}95^{\circ} \mathrm{C} / \\
5 \mathrm{~min} .\end{array}$ & $\begin{array}{l}95^{\circ} \mathrm{C} / \\
5 \mathrm{~min} .\end{array}$ & $\begin{array}{l}95^{\circ} \mathrm{C} / \\
5 \mathrm{~min} .\end{array}$ \\
\hline $\begin{array}{c}\text { Desnaturação } \\
\text { inicial }\end{array}$ & $\begin{array}{l}94^{\circ} \mathrm{C} / \\
1 \mathrm{~min} .\end{array}$ & $\begin{array}{l}95^{\circ} \mathrm{C} / \\
1 \mathrm{~min} .\end{array}$ & $94^{\circ} \mathrm{C} / 2 \mathrm{~min}$. & $\begin{array}{l}95^{\circ} \mathrm{C} / \\
1 \mathrm{~min} .\end{array}$ & $\begin{array}{l}95^{\circ} \mathrm{C} / \\
1 \mathrm{~min} .\end{array}$ & $\begin{array}{l}95^{\circ} \mathrm{C} / \\
1 \mathrm{~min} .\end{array}$ \\
\hline Hibridação & $\begin{array}{l}55^{\circ} \mathrm{C} / \\
30 \text { seg. }\end{array}$ & $\begin{array}{l}58^{\circ} \mathrm{C} / \\
1 \mathrm{~min} .\end{array}$ & $57^{\circ} \mathrm{C} / 1 \mathrm{~min}$ & $\begin{array}{c}55,4^{\circ} \mathrm{C} / \\
1 \mathrm{~min} .\end{array}$ & $\begin{array}{c}65,4^{\circ} \mathrm{C} / \\
1 \mathrm{~min}\end{array}$ & $\begin{array}{c}55,4^{\circ} \mathrm{C} / \\
1 \mathrm{~min} .\end{array}$ \\
\hline Extensão & $\begin{array}{l}72^{\circ} \mathrm{C} / \\
1 \mathrm{~min}\end{array}$ & $\begin{array}{l}72^{\circ} \mathrm{C} / \\
2 \mathrm{~min}\end{array}$ & $72^{\circ} \mathrm{C} / 1 \mathrm{~min}$ & $\begin{array}{l}72^{\circ} \mathrm{C} / \\
2 \mathrm{~min} .\end{array}$ & $\begin{array}{l}72^{\circ} \mathrm{C} / \\
2 \mathrm{~min}\end{array}$ & $\begin{array}{l}72^{\circ} \mathrm{C} / \\
2 \mathrm{~min} .\end{array}$ \\
\hline $\begin{array}{l}\text { Extensão final } \\
\text { Total de ciclos }\end{array}$ & $\begin{array}{l}72^{\circ} \mathrm{C} / \\
7 \mathrm{~min} \\
37\end{array}$ & $\begin{array}{c}72^{\circ} \mathrm{C} / \\
10 \mathrm{~min} . \\
38\end{array}$ & $72^{\circ} \mathrm{C} / 4 \mathrm{~min}$ & 30 & 30 & 30 \\
\hline
\end{tabular}




\section{Resultados}

A ocorrência dos genes toxigênicos nas cepas analisadas encontra-se disposta na tabela 3. Constatouse que as cepas não apresentaram potencial enterotoxigênico em relação às enterotoxinas clássicas SEA e SEB.

Tabela 3. Pesquisa de genes toxigênicos em isolados de Staphylococcus aureus procedentes de amostras de leite de vacas com mastite do estado de Pernambuco, Brasil

\begin{tabular}{ccc}
\hline Genes & $\begin{array}{c}\text { Quantidade de amostras } \\
\text { positivas }\end{array}$ & Valor relativo (\%) \\
\hline sea & - & - \\
seb & - & - \\
sec & 7 & 35,0 \\
seg & 2 & 10,0 \\
$t s t$ & 11 & 55,0 \\
\hline Total & $\mathbf{2 0}$ & $\mathbf{1 0 0 , 0}$ \\
\hline
\end{tabular}

Entre os 20 isolados que continham os genes $s e c, s e g$ e $t s t, 16(80 \%)$ possuíam apenas um dos genes testados e quatro $(20 \%)$ possuíam dois genes $(\mathrm{sec}+t s t)$.

Os isolados foram originários de 17 propriedades leiteiras, e sete $(41,2 \%)$ apresentaram amostras positivas para pelo menos um dos genes sec, seg e tst, como observado na Tabela 4.

Tabela 4. Presença dos genes sec, seg e tst em isolados de Staphylococcus aureus procedentes de amostras de leite de vacas com mastite do estado de Pernambuco, Brasil

\begin{tabular}{cccc}
\hline Propriedades & $\begin{array}{c}\text { Amostras sec } \\
\text { positivas }\end{array}$ & $\begin{array}{c}\text { Amostras seg } \\
\text { positivas }\end{array}$ & Amostras tst positivas \\
\hline P2 $(n=8)$ & - & $2(25,0 \%)$ & - \\
P6 $(n=4)$ & $1(25,0 \%)$ & - & - \\
P13 $(n=9)$ & $3(33,0 \%)$ & - & $2(22,0 \%)$ \\
P14 $(n=8)$ & - & - & $2(25,0 \%)$ \\
P15 $(n=6)$ & - & - & $2(33,0 \%)$ \\
P16 $(n=7)$ & $2(28,0 \%)$ & - & $4(57,0 \%)$ \\
P17 $(n=22)$ & $1(45,0 \%)$ & - & $1(45,0 \%)$ \\
\hline
\end{tabular}

Total

7

2

11 


\section{Discussão}

Ao analisar a ocorrência de genes enterotoxinogênicos, observou-se que 21,6\% (20/93) das amostras possuíam ao menos um dos genes pesquisados. Este é o primeiro registro da ocorrência dos genes sec e tst em cepas de $S$. aureus isoladas a partir de casos de mastite bovina no estado de Pernambuco, Brasil.

A ocorrência observada neste estudo para os genes $\sec (35,0 \%)$ e tst $(55,0 \%)$ foi superior à obtida por Lamaita et al. ${ }^{(6)}$ em Minas Gerais, que detectaram 14,4\% para o gene sec e 0,7\% para o tst em cepas de Staphylococcus spp. isoladas de amostras de leite. Enquanto Nader Filho et al. ${ }^{(16)}$ identificaram a ocorrência em 38,9\% (sec) e 37,5\% (tst) nas amostras analisadas. Dias et al. ${ }^{(7)}$ detectaram o gene sec em 6,9\% (10/145) das amostras de $S$. aureus isoladas de leite bovino. A presença da EEC e TSST-1 já foi associada a quadros de mastite bovina clínica e possui importância na virulência das amostras de $S$. aureus, sugerindo uma relação entre sua presença e a gravidade dos casos de mastite ${ }^{(17)}$.

No estado de Pernambuco, outros estudos já foram conduzidos com o objetivo de detectar a presença dessas toxinas em leite bovino, sendo as amostras negativas para esses genes ${ }^{(18,19)}$. A diferença identificada entre este estudo e os demais pode estar relacionada com a diversidade genética dos micro-organismos em cada localidade.

O gene seg foi o que apresentou menor ocorrência (10,0\%). A pequena porcentagem de cepas de $S$. aureus que apresentam esse gene pode ser explicada por mutações pontuais no próprio gene ou por variações no cluster em que este gene está localizado ${ }^{(20)}$. O seg pode estar localizado em elementos genéticos móveis (plasmídeos); devido à estocagem dos isolados e à temperatura mantida no armazenamento, este gene pode ter desaparecido, já que não haveria necessidade desse elemento para sobrevivência bacteriana ${ }^{(21)}$.

Ao analisar a presença da associação entre genes codificadores, observou-se a associação do gene tst com o sec em quatro isolados (20\%). Em estudo realizado anteriormente, isolados de $S$. aureus de leite de vacas com mastite bovina, foram todos positivos para a presença do gene tst associado com $\mathrm{o}$ gene $\sec ^{(22)}$. A presença do tst associado com outros genes enterotoxigênicos pode indicar o aumento da patogenicidade de $S$. aureus $^{(15)}$. Estudos mais específicos devem ser realizados para verificar a patogênese e a severidade da mastite bovina causada pela associação do gene tst com os demais genes das enterotoxinas estafilocócicas.

A não ocorrência dos genes sea e seb foi semelhante aos resultados obtidos por outros estudos realizados em Pernambuco ${ }^{(18,19)}$. No Japão, os genes das toxinas clássicas também não foram observados em 21 isolados de leite de vacas com mastite ${ }^{(23)}$. Os perfis dos genes para as EEs parecem ser variáveis entre as origens geográficas. Essa diferença pode ser resultado de adaptações do hospedeiro de $S$. aureus nas diferentes espécies animais ${ }^{(24)}$.

O leite é um excelente substrato para a proliferação de micro-organismos, sendo essencial a temperatura da glândula mamária bovina para produção das enterotoxinas e, por isto, podem ser encontradas facilmente no leite bovino ${ }^{(16)}$. Apenas a detecção dos genes toxigênicos em $S$. aureus não implica que estes isolados produzam EEs em nível suficiente para causar quadros de toxinfecção alimentar ou outras doenças associadas às enterotoxinas. Existem também os fatores ambientais (como $\mathrm{pH}$ e atividade de água) que podem desencadear o desenvolvimento da toxinfecção ${ }^{(25)}$. 


\section{Conclusão}

Este foi o primeiro registro da ocorrência de genes codificadores da enterotoxina SEC e da toxina 1 da síndrome do choque tóxico (TSST-1) em amostras de leite de vacas no estado de Pernambuco, Brasil. Deve-se dar importância à presença de genes codificadores de enterotoxinas estafilocócicas em leite de vaca, uma vez que estas representam um potencial fator de risco para a saúde pública.

\section{Referências}

1. Xu SX, Mccormick JK. Staphylococcal superantigens in colonization and disease. Frontiers in Cellular and Infection Microbiology. 2012;52(2):105-115.

2. Boynukara B, Gulhan T, Alisarli M, Gurturk K, Solmaz H. Classical enterotoxigenic characteristics of Staphylococcus aureus strains isolated from bovine subclinical mastitis in Van, Turkey. International Journal of Food Microbiology. 2008;125(2):209-211. http://ac.els-cdn.com/S0168160508001487/1-s2.0S0168160508001487-

main.pdf? tid=05bca2c85ff411 e6936000000aab0f02\&acdnat=1470941415 0109efdbc5fa1deed6c81c87914 $\underline{\mathrm{a} 217 \mathrm{~b}}$

3. Rahimi E, Safai HG. Detection of classical enterotoxins of Staphylococcus aureus strains isolated from bovine subclinical mastitis in Isfahan, Iran. Veterinary Microbiology. 2010;141(3):393-394. http://www.sciencedirect.com/science/article/pii/S0378113509004404

4. Zschöck M, Botzler D, Blöcher S, Sommerhäuser J, Hamann HP. Detection of genes for enterotoxins (ent) and toxic shock syndrome toxin-1 (tst) in mammary isolates of Staphylococcus aureus by polymerase-chain$\begin{array}{llll}\text { reaction. International Dairy 2000;10(8):569-574. } & \text { Journal. }\end{array}$ http://www.sciencedirect.com/science/article/pii/S0958694600000844

5. Cardoso HFT, Carmo LS, Silva N. Detecção da toxina-1 da síndrome do choque tóxico em amostras de Staphylococcus aureus isoladas de mastite bovina. Arquivo Brasileiro de Medicina Veterinária e Zootecnia. 2000;52(1):7-10.

http://www.scielo.br/scielo.php?script=sci arttext\&pid=S0102$\underline{09352000000100002 \& \operatorname{lng}=\text { en\&nrm }=\text { iso }}$

6. Lamaita HC, Cerqueira MMOP, Carmo LS, Santos DA, Penna CFAM, Souza MR. Contagem de Staphylococcus sp. e detecção de enterotoxinas estafilocócicas e toxina da síndrome do choque tóxico em amostras de leite cru refrigerado. Arquivo Brasileiro de Medicina Veterinária e Zootecnia. 2005;57(5):702709. http://www.scielo.br/scielo.php?script=sci_arttext\&pid=S0102-09352005000500017

7. Dias NL, Silva DCB, Oliveira DCBS, Fonseca Júnior AA, Sales ML, Silva N. Detecção dos genes de Staphylococcus aureus, enterotoxinas e de resistência à meticilina em leite. Arquivo Brasileiro de Medicina Veterinária e Zootecnia. 2011;63(6):1547-1552. http://www.scielo.br/pdf/abmvz/v63n6/36.pdf

8. Freitas MF, Luz IDS, Silveira-Filho VDM, Pinheiro Junior JW, Stamford TL, Mota RA, Sena MJ, Ameida AMP, Leal-Balbino TC. Staphylococcal toxin genes in strains isolated from cows with subclinical mastitis. Pesquisa Veterinária Brasileira. 2008;28(12):617-621. http://www.scielo.br/pdf/pvb/v28n12/a10v2812.pdf

9. Wade JT, Reppas NB, Church GM, Struhl K. Genomic analysis of LexA binding reveals the permissive nature of the Escherichia coli genome and identifies unconventional target sites. Genes \& Development. 2005;19(21):2619-2630. http://genesdev.cshlp.org/content/19/21/2619.full.pdf +html

10. Ausubel FM. Current Protocols in Molecular Biology. New York, John Wiley \& Sons, 1989.

11. Kateete DP, Kimani CN, Katabazi FA, Okeng A, Okee MS, Nanteza A, Joloba ML, Najjuka FC. 
Identification of Staphylococcus aureus: DNAse and mannitol salt agar improve the efficiency of the tube coagulase test. Annals of Clinical Microbiology and Antimicrobials. 2010;9(23):1-7. http://annclinmicrob.biomedcentral.com/articles/10.1186/1476-0711-9-23

12. Becker K, Roth R, Peters G. Rapid and specific detection of toxigenic Staphylococcus aureus: Use of two multiplex PCR enzyme immunoassays for amplification and hybridization of staphylococcal enterotoxin genes, exfoliativetoxin genes, and toxic shock syndrome toxin 1 gene. Journal of Clinical Microbiology. 1998;36(9):2548-2553. http://jcm.asm.org/content/36/9/2548.full.pdf + html

13. Mehrotra M, Wang G, Johnson WM. Multiplex PCR for detection of genes for Staphylococcus aureus enterotoxins, exfoliative toxins, toxic shock syndrome toxin 1, and methicillin resistance. Journal of Clinical Microbiology. 2000;38(3):1032-1035. http://jcm.asm.org/content/38/3/1032.full.pdf + html

14. Monday SR, Bohach GA. Use of multiplex PCR to detect classical and newly described pyrogenic toxin genes in staphylococcal isolates. Journal of Clinical Microbiology. 1999;37(10):3411-3414. http://jcm.asm.org/content/37/10/3411.full.pdf +html

15. Karahan M, Açik MN, Cetinkaya B. Investigation of Toxin Genes by Polymerase Chain Reaction in Staphylococcus aureus strains isolated from bovine mastitis in Turkey. Foodborne Pathogens and Disease. 2009;6(8):1029-1035. http://online.liebertpub.com/doi/abs/10.1089/fpd.2009.0304

16. Nader Filho A, Ferreira LM, Amaral LA, Rossi Junior OD, Oliveira RP. Produção de enterotoxinas e da toxina da síndrome do choque tóxico por cepas de Staphylococcus aureus isoladas na mastite bovina. Arquivo Brasileiro de Medicina Veterinária e Zootecnia. 2007;59(5):1316-1318. http://www.scielo.br/pdf/abmvz/v59n5/a32v59n5.pdf

17. Sá MEP, Cunha MLRS, Elias AO, Victória C, Langoni H. Importância do Staphylococcus aureus nas mastites subclínicas: pesquisa de enterotoxinas e toxina do choque tóxico, e a relação com a contagem de células somáticas. Brazilian Journal of Veterinary Research and Animal Science. 2004;41(5):320-326. http://www.scielo.br/pdf/\%0D/bjvras/v41n5/25256.pdf

18. Freitas MFL, Pinheiro Junior JW, Stamford TLM, Rabelo SSA, Silva DR, Silveira Filho VM, Santos FGB, Sena MJ, Mota RA. Perfil de sensibilidade antimicrobiana in vitro de Staphylococcus coagulase positivos isolados do leite de vacas com mastite no Agreste do estado de Pernambuco. Arquivos do Instituto Biológico. 2005;72(2):171-177. http://200.144.6.109/docs/arq/V72_2/freitas.PDF

19. Luz IS. Caracterização molecular das toxinas em Staphylococcus aureus isolados de leite e queijo de coalho em municípios da região agreste de Pernambuco. Centro de Pesquisas Aggeu Magalhães, Fundação Oswaldo Cruz 2008. 126f Dissertação de Mestrado, Recife, http://arca.icict.fiocruz.br/bitstream/icict/3952/2/000040.pdf

20. Jarraud S, Peyrat MA, Lim A, Tristan A, Bes M, Mougel C, Etienne J, Vandenesch F, Bonneville M, Lima G. Egc a highly prevalent operon of enterotoxin gene, forms a putative nursey of superantigens in Staphylococcus aureus. The Journal of Immunology. 2001;166(1):669-677. http://www.jimmunol.org/content/166/1/669.full.pdf+html

21. Bennett PM. Plasmid encoded antibiotic resistance: acquisition and transfer of antibiotic resistance genes in bacteria: Review. British Journal of Pharmacology. 2008;153(1):347-357. http://onlinelibrary.wiley.com/doi/10.1038/sj.bjp.0707607/pdf

22. Akineden Ö, Anne Müller C, Hassan AA, Lämmler C, Wolter W, Zschöck M. Toxin genes and other characteristics of Staphylococcus aureus isolates from milk of cows with mastitis. Clinical and Diagnostic Laboratory Immunology. 2001;8(5):959-964. http://cvi.asm.org/content/8/5/959.full.pdf+html

23. Omoe K, Ishikawa M, Shimoda Y, Hu DL, Ueda S, Shinagawa K. Detection of seg, seh and sei genes in Staphylococcus aureus isolates and determination of the enterotoxin productivities of $S$. aureus isolates 
harboring seg, seh or sei genes. Journal of Clinical Microbiology. 2002;40(3):857-862. http://jcm.asm.org/content/40/3/857.full.pdf + html

24. Hwang SY, Kim SH, Jang EJ, Kwon NH, Kwon YK, Koo HC, Jung WK, Kim JM, Park YH. Novel multiplex PCR for the detection of the Staphylococcus aureus superantigen and its application to raw meat isolates in Korea. International Journal of Food Microbiology. 2007;117(1):99-105. http://www.sciencedirect.com/science/article/pii/S0168160507001572

25. Chiang YC, Liao WW, Fan CM, Pai WY, Chiou CS, Tsen HY. PCR detection of Staphylococcal enterotoxins (SEs) N, O, P, Q, R, U, and survey of SE types in Staphylococcus aureus isolates from foodpoisoning cases in Taiwan. 2008;(1)121:66-73. http://ac.els-cdn.com/S0168160507005594/1-s2.0S0168160507005594-

main.pdf? tid=6004ad425ff511e68e2d00000aacb35f\&acdnat=1470941996_479401fc2e95cc4e8d7aa54d26b $\underline{0 \mathrm{fe} 47}$ 